\title{
A Simple and Fast Method to Sequence the Full-Length Spike Gene for SARS-CoV-2 Variant Identification from Patient Samples
}

\author{
Patricia Recordon-Pinson 1,2 ${ }^{\mathbb{D}}$, Marie-Lise Blondot ${ }^{1,2}$, Pantxika Bellecave ${ }^{3}$, Marie-Edith Lafon ${ }^{1,3}$, \\ Camille Tumiotto ${ }^{1,3}$, Mathieu Métifiot ${ }^{1, *(D)}$ and Marie-Line Andreola ${ }^{1,2}$ \\ 1 Microbiologie Fondamentale et Pathogénicité, CNRS-UMR 5234, Université de Bordeaux, \\ F-33000 Bordeaux, France; patricia.recordon-pinson@u-bordeaux.fr (P.R.-P.); \\ marie-lise.blondot@u-bordeaux.fr (M.-L.B.); marie-edith.lafon@u-bordeaux.fr (M.-E.L.); \\ camille.tumiotto@chu-bordeaux.fr (C.T.); marie-line.andreola@u-bordeaux.fr (M.-L.A.) \\ 2 SBM Department, UB'L3 Platform, Université de Bordeaux, F-33000 Bordeaux, France \\ 3 CHU Bordeaux, Virology Laboratory, Université de Bordeaux, F-33000 Bordeaux, France; \\ pantxika.bellecave@chu-bordeaux.fr \\ * Correspondence: mathieu.metifiot@u-bordeaux.fr; Tel.: +33-55-757-1739
}

check for updates

Citation: Recordon-Pinson, P.; Blondot, M.-L.; Bellecave, P.; Lafon, M.-E.; Tumiotto, C.; Métifiot, M.; Andreola, M.-L. A Simple and Fast Method to Sequence the Full-Length Spike Gene for SARS-CoV-2 Variant Identification from Patient Samples. COVID 2021, 1, 337-344. https:/ / doi.org/10.3390/covid1010028

Academic Editors:

Dimitrios Paraskevis,

Maria Yavropoulou and

Sotirios Tsiodras

Received: 8 July 2021

Accepted: 1 September 2021

Published: 3 September 2021

Publisher's Note: MDPI stays neutral with regard to jurisdictional claims in published maps and institutional affiliations.

Copyright: (c) 2021 by the authors. Licensee MDPI, Basel, Switzerland. This article is an open access article distributed under the terms and conditions of the Creative Commons Attribution (CC BY) license (https:/ / creativecommons.org/licenses/by/ $4.0 /)$.

\begin{abstract}
Since the beginning of the pandemic, a race has been underway to detect SARS-CoV-2 virus infection (PCR screening, serological diagnostic kits), treat patients (drug repurposing, standard care) and develop a vaccine. After almost a year of active circulation worldwide, SARS-CoV-2 variants have appeared in different countries. Those variants include mutations in multiple regions of the genome, particularly in the spike gene. Because this surface protein is a key player in both the spread of the virus and the efficacy of vaccine strategies, the challenge is to efficiently monitor the appearance of spike mutations in the population. The present work describes a procedure based on the widely available Sanger technology to produce a full-length sequence of the spike gene from patient-derived samples.
\end{abstract}

Keywords: SARS-CoV-2; sanger sequencing; circulating variants; COVID-19

\section{Introduction}

In late 2019, severe acute respiratory syndrome coronavirus 2 (SARS-CoV-2) emerged in Wuhan, Hubei province, China. This local outbreak rapidly developed into the COVID19 pandemic [1,2]. At the end of March 2021, the total number of cases was estimated to be 128 million (https: / / coronavirus.jhu.edu, 29 March 2021). Since the middle of 2020, there have been hundreds of thousands of new infections each day, with peaks approaching one million. Unsurprisingly, several new variants have emerged during this expansion, some of which have become variants of interest, or even variants of concern (VOC) [3]. Their prevalence in the population quickly increased and the majority of new infections are now due to these variants rather than the parental strain. Mutations have been described in the $5^{\prime}$ untranslated region (UTR), ORF1ab, ORF3a, Spike, M, ORF8 and N. Therefore, monitoring the genetic evolution in the SARS-CoV-2 virus is becoming a top priority in the management of the COVID-19 pandemic.

The entry of coronaviruses is mediated by the surface glycoprotein spike [4-6]. Because of its role in receptor binding, the spike protein was quickly found to be the best candidate for producing neutralizing antibodies [7]. Current vaccines and novel therapeutic strategies under development are based on this spike protein. Accordingly, it is crucial to monitor the appearance of mutations in circulating viruses that might affect collective as well as acquired immunity.

The first described amino acid mutation was a D to $G$ transition in the spike coding region (D614G) [8]. Observed in Europe as early as February 2020, this variation increased 
viral replication/infectivity [9]. It is now present in almost all circulating viruses and is shared among all of the current variants of interest/concern. Of note, this mutation has also been associated with an increased susceptibility to neutralizing antibodies [10]. Conversely, other mutations, such as the N501Y and E484K mutations located in the receptor-binding domain of spike (RBD), can affect the immunity conferred by polyclonal antibodies. The United Kingdom (UK) variant, also known as VOC 202012/01 (Nextstrain 20I/501Y.V1, PANGO lineage B.1.1.7), emerged in the south-east of the country in December 2020 [11]. In addition to the D614G, it harbored multiple mutations including N501Y, as well as a deletion at positions 69/70, affecting the diagnostic capacity of PCR tests involving the S region (Table 1, Alpha).

Table 1. List of reported mutations for the three VOCs and the 20A.EU2 (corresponding to SARS CoV2 clade which dominated the European second outbreak in 2020) compared to the reference Wuhan strain (WIV04/2019).

\begin{tabular}{|c|c|c|c|c|c|c|}
\hline Strain & WIV04/2019 & 20A.EU2 & Alpha & Beta & Gamma & Delta \\
\hline AA position on spike $\backslash \#$ & $\mathrm{~N} / \mathrm{A}$ & 2 & 10 & 12 & 12 & 12 \\
\hline 18 & $\mathrm{~L}$ & & & $\mathrm{~F}$ & $\mathrm{~F}$ & \\
\hline 19 & $\mathrm{~T}$ & & & & & $\mathrm{R}$ \\
\hline 20 & $\mathrm{~T}$ & & & & $\mathrm{~N}$ & \\
\hline 26 & $\mathrm{P}$ & & & & S & \\
\hline 69 & $\mathrm{H}$ & & - & & & \\
\hline 70 & $\mathrm{~V}$ & & - & & & \\
\hline 80 & $\mathrm{D}$ & & & A & & \\
\hline 138 & $\mathrm{D}$ & & & & Y & \\
\hline 142 & G & & & & & $\mathrm{D}$ \\
\hline 144 & $\mathrm{Y}$ & & - & & & \\
\hline 154 & $\mathrm{E}$ & & & & & K \\
\hline 157 & $\mathrm{~F}$ & & & & & - \\
\hline 158 & $\mathrm{R}$ & & & & & - \\
\hline 190 & $\mathrm{R}$ & & & & S & \\
\hline 215 & $\mathrm{D}$ & & & G & & \\
\hline 242 & $\mathrm{~L}$ & & & - & & \\
\hline 243 & A & & & - & & \\
\hline 244 & $\mathrm{~L}$ & & & - & & \\
\hline 246 & $\mathrm{R}$ & & & I & & \\
\hline 417 & K & & & $\mathrm{N}$ & $\mathrm{T}$ & \\
\hline 452 & $\mathrm{~L}$ & & & & & R \\
\hline 477 & $S$ & $\mathrm{~N}$ & & & & \\
\hline 478 & $\mathrm{~T}$ & & & & & K \\
\hline 484 & $\mathrm{E}$ & & & K & K & Q \\
\hline 501 & $\mathrm{~N}$ & & Y & Y & $Y$ & \\
\hline 570 & A & & D & & & \\
\hline 614 & D & G & G & G & G & G \\
\hline 655 & $\mathrm{H}$ & & & & $\mathrm{Y}$ & \\
\hline 681 & $\mathrm{P}$ & & $\mathrm{H}$ & & & R \\
\hline 701 & A & & & V & & \\
\hline 716 & $\mathrm{~T}$ & & I & & & \\
\hline 950 & $\mathrm{D}$ & & & & & $\mathrm{N}$ \\
\hline 982 & $S$ & & A & & & \\
\hline 1027 & $\mathrm{~T}$ & & & & I & \\
\hline 1071 & $\mathrm{Q}$ & & & & & $\mathrm{H}$ \\
\hline 1118 & $\widehat{\mathrm{D}}$ & & $\mathrm{H}$ & & & \\
\hline 1176 & $\mathrm{~V}$ & & & & $\mathrm{~F}$ & \\
\hline
\end{tabular}

\# = total number of mutations compared to the reference sequence. Deletions are indicated with a minus (-) sign Signature mutations are highlighted in green, while mutations that could impact viral infectivity and/or immune response are in red.

Soon thereafter, another VOC was identified with a similar N501Y transition but in South Africa [12]. Known as 20H/Beta or B.1.351, this variant (Table 1, Beta) appeared independently of the alpha virus and presented additional transitions including the spike 
E484K. Finally, a third VOC was identified in Brazil. Known as P.1 or 20J/501Y.V3, this variant shared some spike mutations seen in the beta virus. In all cases, numerous other mutations can be associated with these major variants, and new mutations are appearing constantly. That is the case, for example, with the BRE-IPP03921 variant, which recently emerged in Brittany, France, and which was identified after a recrudescence of COVID-19 symptoms in patients who tested negative for SARS-CoV-2 by routine PCR screening. More recently, the VOC delta (B.1.617.2), first described in India, is now spreading in the United Kingdom and all around Western Europe [13].

Overall, all variants harbour mutations in the viral spike, and these mutations spread throughout the protein sequence. However, present sequencing protocols of the spike cover two regions (genome positions 21,701 to 22,344 and 22,763 to 23,310), while sequencing of the whole spike is performed by NGS when a variant is suspected. Next generation sequencing would be the best solution to obtain a full-length spike sequence or even a whole genome sequence in order to survey any kind of mutation. Still, the required technology is absent in most southern countries and is not even readily available in every hospital in Europe. In contrast, Sanger is more widely available and makes it possible to obtain $800-1000$ base reads per run. However, the SARS-CoV-2 spike is a 1273-amino acid protein encoded by the corresponding 3822-base open reading frame. Accordingly, we developed a procedure based on Sanger technology to sequence the full-length spike in three steps from nasal or saliva screening swab extracts. This procedure is compatible with other patient-derived samples such as bronchoalveolar lavages (BAL). The entire process can be performed in less than $14 \mathrm{~h}$ and provides sufficient coverage to identify existing and future novel variants.

\section{Materials and Methods}

Clinical Sample Collection. Patient samples were obtained from the Bordeaux university Hospital virology laboratory. To validate the protocol, various types of clinical samples were used. Twelve among 15 samples were RNA extracts from patients tested at the hospital COVID-19 centre as positive by qualitative real-time RT-PCR (nasal swabs). Three samples were RNA extracted from broncho-alveolar lavages (BAL). The last one (culture strain) consisted of RNA extracts from culture supernatant of Vero E6 cells infected with a reference strain (WIV04/2019 obtained through the EVAg and Pasteur Institute). Infection was performed in the BSL3 facility of Bordeaux University (UB'L3) as described in our recent work [14]. Ct values of RT-qPCR were determined during patient follow-up in the hospital using SARS-CoV-2 R-gene (BioMérieux, Craponne, France) and GeneFinder ${ }^{\mathrm{TM}}$ COVID-19 PLUS RealAmp (Osang Healthcare, Gyeonggi-do, Korea) kits.

RNA extraction. A pure viral RNA kit from Roche was used to extract RNA from samples of either BAL or cell culture supernatant $(200 \mu \mathrm{L})$. After binding and washes, elution was performed with $50 \mu \mathrm{L}$ of water. The quality of the extraction was checked by monitoring the absorbance profile using a NanoDrop 2000 (ThermoFisher scientific, Waltham, MA, USA).

Amplification of the spike gene. Primers used for amplification and sequencing were purchased from Eurofins Genomics (Germany), and are reported in Table 2. Amplification of a single fragment of $4200 \mathrm{bp}$ covering the entire spike gene was performed from $10 \mu \mathrm{L}$ of extracted viral RNA, as previously described [15]. RT-PCR was carried out in $25 \mu \mathrm{L}$ reaction using forward F1- 1 and reverse F1-1 primers $(0.4 \mu \mathrm{M}$ of each primer) in a buffer containing $0.4 \mathrm{mM}$ of each dNTP, $3.2 \mathrm{mM} \mathrm{MgSO}_{4}$ and 0.5 unit of SuperScript ${ }^{\mathrm{TM}}$ III RT/Platinum ${ }^{\mathrm{TM}}$ Taq Mix (Invitrogen, ThermoFisher Scientific, Waltham, MA, USA). After an initial RT step performed at $50^{\circ} \mathrm{C}$ for $30 \mathrm{~min}$, the $\mathrm{PCR}$ cycling program consisted of a denaturation at $95^{\circ} \mathrm{C}$ for $2 \mathrm{~min}$ followed by 30 cycles of $95{ }^{\circ} \mathrm{C}$ for $30 \mathrm{~s}, 60^{\circ} \mathrm{C}$ for $15 \mathrm{~s}$ and $68{ }^{\circ} \mathrm{C}$ for $5 \mathrm{~min}$. The reaction concluded with a final extension at $68^{\circ} \mathrm{C}$ for $5 \mathrm{~min}$. A nested PCR was performed with $2 \mu \mathrm{L}$ of this RT-PCR product at a final volume of $25 \mu \mathrm{L}$ using $0.8 \mu \mathrm{M}$ of each primer (forward F1-2 and reverse F1) in a reaction buffer containing $15 \mathrm{mM}$ of $\mathrm{MgCl}_{2}$, $5 \mathrm{mM}$ of dNTPs and 0.25 unit of ThermoSTAR 2 HS Taq (Eurobio, Les Ulis, France). The 
quality of the PCR products was verified by electrophoresis using a QIAxcel Advanced automate (Qiagen, Germantown, MD, USA) before cleaning using ExoSAP-IT ${ }^{\mathrm{TM}}$ PCR Product Cleanup Reagent kit (Applied Biosystems, ThermoFisher scientific, Waltham, MA, USA).

Table 2. Primers used in this study.

\begin{tabular}{|c|c|c|c|c|}
\hline & Primer Name & Sequence & $\begin{array}{l}\text { Positions (Ref. } \\
\text { NC_045512.2) }\end{array}$ & Reference \\
\hline \multirow{2}{*}{ RT-PCR } & Forward F1-1 & GCATGGTGGACAGCCTTTGT & 21,220 to 21,239 & \multirow{4}{*}{ [7] } \\
\hline & Reverse F1-1 & TGGGTTTTTGGAACGGCATT & 25,787 to 25,806 & \\
\hline \multirow{2}{*}{$\begin{array}{l}\text { Nested PCR } \\
+ \text { sequencing }\end{array}$} & Forward F1-2 & GGGGTACTGCTGTTATGTCTTT & 21,422 to 21,443 & \\
\hline & Reverse F1-2 & CACCCTTGGAGAGTGCTAGT & 25,602 to 25,621 & \\
\hline \multirow{8}{*}{ Sequencing } & nCoV-2019_76_LEFT & AGGGCAAACTGGAAAGATTGCT & 22,798 to 22,819 & \multirow{2}{*}{ ANRS AC43 } \\
\hline & nCoV-2019_76_RIGHT & ACCTGTGCCTGTTAAACCATTGA & 23,190 to 23,212 & \\
\hline & CV_14_F & CAGGCTGCGTTATAGCTTGGAA & 22,851 to 22,872 & \multirow{4}{*}{$\mathrm{CDC}$} \\
\hline & CV_14_R & AACCAGTGTGTGCCATTTGAA & 24,870 to 24,850 & \\
\hline & CV_15_F & GCAGAAATCAGAGCTTCTGCTAATC & 24,608 to 24,632 & \\
\hline & SARS2_B6F & CCAGCAACTGTTTGTGGACCTA & 23,123 to 23,144 & \\
\hline & SARS SMF & TCAATCCATCATTGCСТACAC & 23,629 to 23,649 & \multirow{2}{*}{ This work } \\
\hline & SARS S3R & GAGCAAAGGTGGCAAAACAG & 24,138 to 24,157 & \\
\hline
\end{tabular}

Sanger Sequencing and sequences analysis. Purified PCR products were sequenced using the BigDye ${ }^{\circledR}$ Terminator v3.1 Cycle Sequencing Kit on an Applied Biosystems 3500XL DX automat (Applied Biosystems, ThermoFisher Scientific, Waltham, MA, USA). For that, ten sequencing reactions were performed, each using $2 \mu \mathrm{L}$ of nested PCR products, and using primers F1-2 and F1-2 plus eight additional primers (Table 2). Abi files were either aligned to the reference SARS-CoV-2 genome in SnapGene 4.3.11 or uploaded to the SmartGene IDNS software Coronavirus Module (IDNS ${ }^{\circledR}$ version v3_11_0r2(r32344) @ SmartGene 2021).

\section{Results}

The aim of this work was to establish a robust but simple, fast procedure to generate sequencing data on the full-length spike gene using Sanger technology. Since the beginning of 2020, several hundreds of thousands of people have been screened every day for SARSCoV-2 infection. Accordingly, there are a tremendous number of samples that merit further characterization through spike sequencing. The majority of the collected samples are nasal swabs that are further processed (RNA extraction) for RT-qPCR detection of two to three viral genes. We intended to make use of these PCR positive samples that were already extracted to enable subsequent full-length spike gene sequencing. Sequencing was performed for 16 samples from patients, comprising 8 males and 7 females. Ct values ranged from 15.14 to 35.76 for the $\mathrm{N}$ gene, and 16.6 to undetectable $(\mathrm{Ct}>40)$ for the $\mathrm{RdRp}$ gene (Table 3). For some samples, E gene screening was also performed and $\mathrm{Ct}$ values ranged from 13.53 to 25.64 (Table 3 ). 
Table 3. Clinical samples characteristics and spike sequence.

\begin{tabular}{|c|c|c|c|c|c|c|c|c|}
\hline \multirow{2}{*}{$\begin{array}{l}\text { Sample } \\
\text { Type }\end{array}$} & \multirow{2}{*}{$\begin{array}{l}\text { Sampling } \\
\text { Date }\end{array}$} & \multirow{2}{*}{ Sex } & \multicolumn{3}{|c|}{ Ct RTqPCR } & \multirow{2}{*}{ Known Spike Mutations } & \multirow{2}{*}{$\begin{array}{l}\text { Others Spike } \\
\text { Mutations }\end{array}$} & \multirow{2}{*}{ Variant } \\
\hline & & & $\mathbf{N}$ & RdRp & $\mathbf{E}$ & & & \\
\hline $\begin{array}{l}\text { Nasal } \\
\text { swab }\end{array}$ & Feb 2021 & $\mathrm{M}$ & 28.79 & 28.79 & ND & $\begin{array}{c}\text { del69-70, del144, N501Y, } \\
\text { A570D, D614G, P681H, } \\
\text { T716I, S982A, D1118H }\end{array}$ & V6A, Q14Q/P & Alpha \\
\hline $\begin{array}{l}\text { Nasal } \\
\text { swab }\end{array}$ & Feb 2021 & $\mathrm{~F}$ & 31.41 & 31.44 & ND & $\begin{array}{c}\text { del69-70, del144, N501Y, } \\
\text { A570D, D614G, P681R, } \\
\text { T716I, S982A, D1118H }\end{array}$ & & Alpha \\
\hline $\begin{array}{l}\text { Nasal } \\
\text { swab }\end{array}$ & Feb 2021 & $\mathrm{~F}$ & 17.68 & 19.39 & ND & $\begin{array}{c}\text { del69-70, del144, N501Y, } \\
\text { A570D, D614G, P681H, } \\
\text { T716I, S982A, D1118H }\end{array}$ & $\begin{array}{c}\mathrm{V} 47 \mathrm{~V} / \mathrm{I}, \mathrm{A} 831 \mathrm{~V}, \\
\mathrm{~T} 998 \mathrm{~T} / \mathrm{P} \\
\mathrm{T} 1006 \mathrm{~T} / \mathrm{P}\end{array}$ & Alpha \\
\hline $\begin{array}{l}\text { Nasal } \\
\text { swab }\end{array}$ & Feb 2021 & M & 20.26 & 21.62 & ND & $\begin{array}{c}\text { del69-70, del144, N501Y, } \\
\text { A570D, D614G, P681H, } \\
\text { T716I, S982A, D1118H }\end{array}$ & V6A & Alpha \\
\hline $\begin{array}{l}\text { Nasal } \\
\text { swab }\end{array}$ & Feb 2021 & $\mathrm{~F}$ & 24.91 & 25.50 & ND & $\begin{array}{c}\text { del69-70, del144, N501Y, } \\
\text { A570D, D614G, P681R, } \\
\text { T716I, S982A, D1118H }\end{array}$ & & Alpha \\
\hline $\begin{array}{l}\text { Nasal } \\
\text { swab }\end{array}$ & Feb 2021 & $\mathrm{~F}$ & 21.37 & 20.90 & ND & $\begin{array}{c}\text { L18F, D80A, D215G, } \\
\text { del242-244, K417N, E484K, } \\
\text { N501Y, D614G, A701V }\end{array}$ & & Beta \\
\hline $\begin{array}{l}\text { Nasal } \\
\text { swab }\end{array}$ & Feb 2021 & $\mathrm{~F}$ & 35.16 & $>40$ & ND & $\begin{array}{c}\text { del69-70, del144, N501Y, } \\
\text { A570D, D614G, P681H, } \\
\text { T716I, S982A, D1118H }\end{array}$ & & Alpha \\
\hline $\begin{array}{l}\text { Nasal } \\
\text { swab }\end{array}$ & Feb 2021 & M & 26.90 & 28.65 & ND & $\begin{array}{l}\text { L18F, L452R, N501Y, A653V, } \\
\text { H655Y, D796Y, G1219V }\end{array}$ & $\begin{array}{l}\text { R346I, Q667H, } \\
\text { K1191N }\end{array}$ & new \\
\hline $\begin{array}{l}\text { Nasal } \\
\text { swab }\end{array}$ & Feb 2021 & $\mathrm{~F}$ & 23.72 & 31.50 & ND & $\begin{array}{c}\text { L18F, L452R, N501Y, A653V, } \\
\text { H655Y, D796Y, G1219V }\end{array}$ & $\begin{array}{l}\text { R346I, Q667H, } \\
\text { K1191N }\end{array}$ & new \\
\hline $\begin{array}{l}\text { Nasal } \\
\text { swab }\end{array}$ & Feb 2021 & M & 35.76 & 31.50 & ND & $\begin{array}{c}\text { del69-70, del144, N501Y, } \\
\text { A570D, D614G, P681H, } \\
\text { T716I, S982A, D1118H }\end{array}$ & $\begin{array}{c}\text { I197I/V, A831V, } \\
\text { D839D/G, } \\
\text { T1238T/I }\end{array}$ & Alpha \\
\hline $\begin{array}{l}\text { Nasal } \\
\text { swab }\end{array}$ & Feb 2021 & $\mathrm{M}$ & 15.14 & 16.58 & 13.53 & D614G & A222V & WT \\
\hline $\begin{array}{l}\text { Nasal } \\
\text { swab }\end{array}$ & Feb 2021 & M & 27.19 & 29.57 & 25.64 & S477N, D614G, G1219C & & 20A.EU2 \\
\hline BAL & $\begin{array}{l}\text { April } \\
2021\end{array}$ & M & 17.90 & 19.43 & 16.89 & $\begin{array}{c}\text { del69-70, del144, N501Y, } \\
\text { A570D, D614G, P681R, } \\
\text { T716I, S982A, D1118H }\end{array}$ & & Alpha \\
\hline BAL & Feb 2021 & $\mathrm{~F}$ & 15.26 & 16.6 & 13.56 & S477N, D614G & $\begin{array}{l}\text { F2L, S459F, } \\
\text { K1045E }\end{array}$ & 20A.EU2 \\
\hline BAL & Feb 2021 & $\mathrm{M}$ & 21.95 & 22.12 & 20.29 & D614G & T29I, Q675H & WT \\
\hline $\begin{array}{c}\text { Cell } \\
\text { culture }\end{array}$ & May 2020 & - & ND & ND & ND & no mutation & no mutation & WT \\
\hline
\end{tabular}

BAL: branchoalveolar lavage, ND: not determined. Mutations that could impact viral infectivity and/or immune response are in red.

First, RNA extracts from nasal swabs were subjected to reverse transcription using primers Forward F1-1 and Reverse F1-1 located in adjacent genes, namely, orf1ab and orf3a, respectively (Table 2). This led to the generation of a 4587-base-pair DNA fragment that was further amplified by nested PCR using primers Forward F1-2 and Reverse F1-2 (Table 2). At this step, the quality of amplification could be assessed if needed through conventional agarose separation or any other electrophoretic method. As seen in Figure 1B, this process from nasal swab extracts allowed us to produce a single band of $4199 \mathrm{bp}$. Before 
further processing, samples were enzymatically cleaned with Exo I and rSAP treatments. Sequencing was performed using $2 \mu \mathrm{L}$ of the PCR mix per primer pair, allowing up to 13 sequencing reactions per sample. We found that six was the minimal number of Sanger reactions necessary to fully cover the $3822 \mathrm{bp}$ spike gene. Deletion events in the $5^{\prime}$ side were unambiguously detected, even with a single read. However, mutations at primer binding sites may affect sequencing efficacy. In addition, the presence of mix bases due to multiple viral populations may interfere with proper base assignment, and higher coverage might be required in hotspot regions. Accordingly, primers were designed to produce a higher overlap ( $4 x$ coverage) at spike amino acids positions 400 to $800(22,760-23,962 \mathrm{nt}$, Figure 1A), because these correspond to the receptor binding domain and represent the most relevant region for variant determination. Thus, we proposed a set of 10 primers to unambiguously sequence the full-length spike gene. Using this protocol, complete sequencing was achieved for all tested samples (Table 3).

A
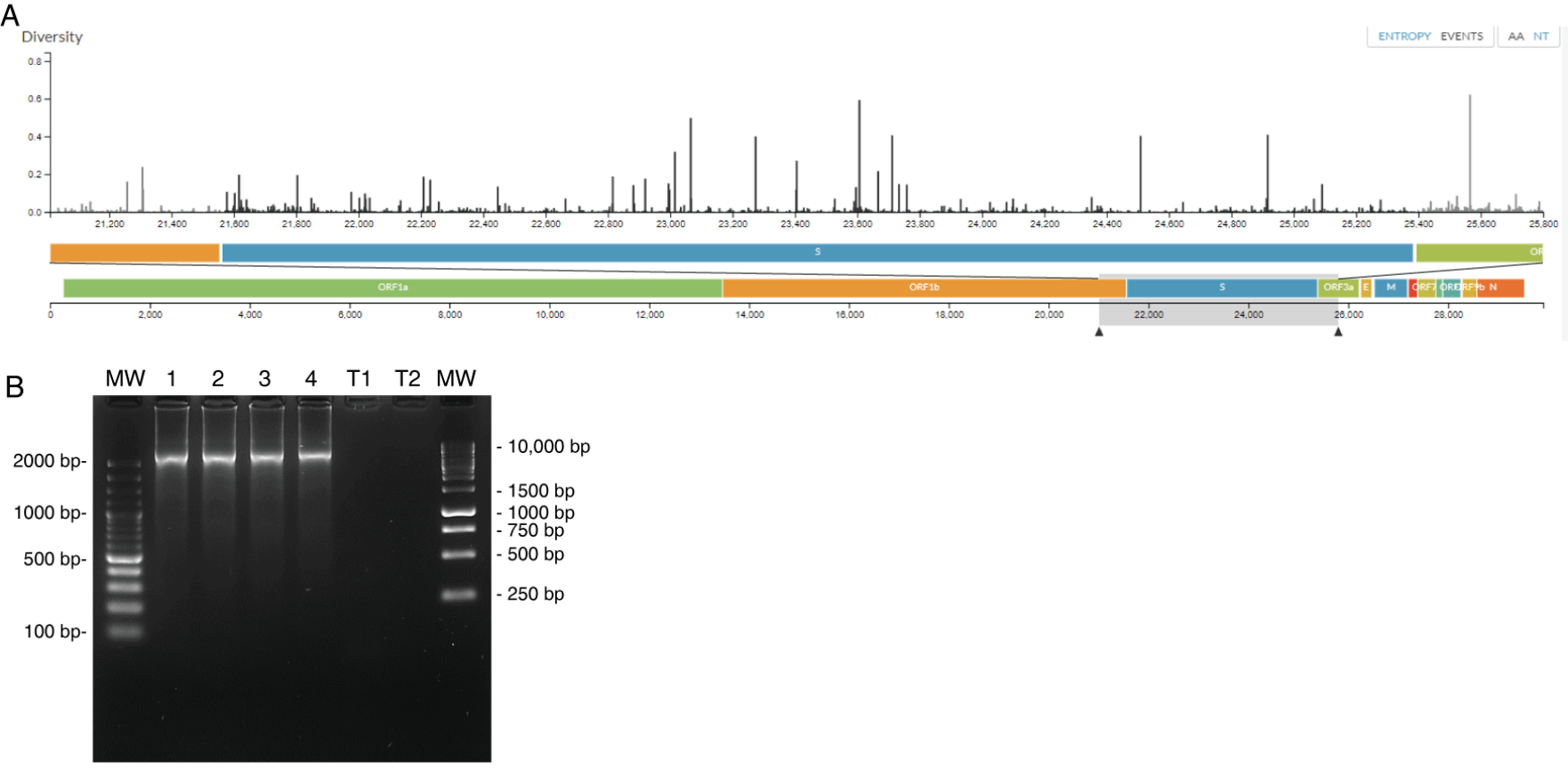

Figure 1. (A). Nucleotide diversity around the spike coding region. Screenshot of the Nextstrain.org website taking into account global GISAID data from 19 December 2020 to 8 April 2021 (top). The bottom panel represents the region amplified following RT-PCR (grey box encompassed by black arrows). (B). Typical quality control gel obtained after nested PCR amplification, M1 and M2 are DNA ladders, 1 to 4 are amplicons from four patients samples and t1-t2 are negative controls of the two steps amplification.

Sequencing could be achieved using various types of samples. In addition to nasal swabs, BAL or cell culture viral supernatants were used as alternative starting materials. In the latter case, RNA extraction was performed using $200 \mu \mathrm{L}$ of sample concentrated to $50 \mu \mathrm{L}$ of total RNA extract. Then, these alternative extracts were used exactly as previously described for the nasal swab extracts. Analyses of sequences were then performed using the SmartGene IDNS software Coronavirus Module (Figure 2). This allowed us to detect mutations in comparison with the reference strain. Combinations of mutations unambiguously allowed us to classify the viruses as WT or in relation to the circulating alpha and beta variants, with alpha representing the most frequent circulating form in our region at this time. In addition to previously reported mutations using current protocols, several additional mutations could be identified in the spike gene, especially the L452R, a mutation found in delta and kappa variants, as well as in epsilon, known to impact antibody binding and increase transmissibility. Interestingly, sequencing data could be obtained similarly from samples arising from screening facility samples, as well as from intensive care unit 
derived samples (BAL). Moreover, our data showed that if necessary, hard to sequence samples could alternatively be amplified in the lab (cell culture viral amplification) without introducing additional mutations (at least on early passages).

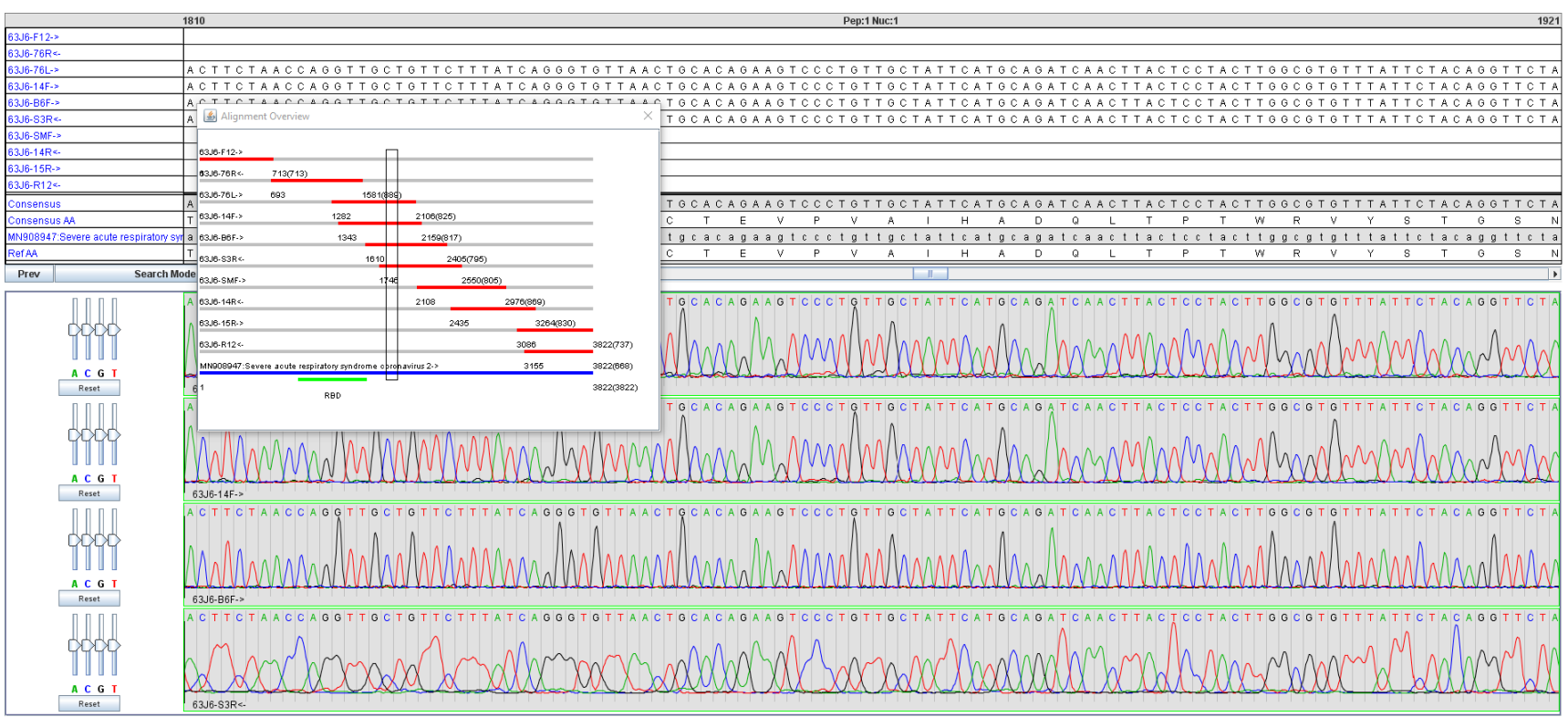

Figure 2. Smartgene IDNS software Coronavirus Module. This is an example of the spike region covered by the 10 amplifications.

\section{Discussion}

Since the original breakout of SARS-CoV-2 at the end of 2019 in China, tremendous effort has been made by the scientific community to better understand the physiopathology of the virus and find effective antivirals and vaccines. Even though several vaccines have been successfully developed in record time, several mutations have arisen which threaten their future efficacy. Altogether, we developed a simple and reliable method to sequence whole spike gene in less than $14 \mathrm{~h}$, directly from RNA extract left over from screening facilities. This protocol is able to unambiguously identify an exhaustive list of known and yet unseen mutations, which will help monitor circulating variants around the world if widely adopted by screening facilities. The surveillance of new variants will certainly be the most significant challenge in future months, and since next generation sequencing is not available in many regions, this simple method, based on Sanger sequencing, appears to be a viable option for global surveillance.

Author Contributions: Sample collection, P.B., M.-E.L. and C.T.; sample preparation, P.R.-P. and M.-L.B. methodology, P.R.-P.; formal analysis, P.R.-P. and M.M.; writing-original draft preparation, P.R.-P. and M.M.; review and editing, M.M. and M.-L.A.; funding acquisition, M.-L.A. All authors have read and agreed to the published version of the manuscript.

Funding: We thank the CNRS and the Bordeaux University for support. This work was supported by the Region Nouvelle-Aquitaine (AMI FLASH Recherche et Innovations COVID). ML Blondot was supported by the Region Nouvelle Aquitaine and UBreACT Mission COVID-19 of Bordeaux University.

Institutional Review Board Statement: Not applicable.

Informed Consent Statement: Not applicable.

Data Availability Statement: Raw sequence data can be obtained directly from the authors.

Conflicts of Interest: The authors declare no conflict of interest. 


\section{References}

1. Zhou, P.; Yang, X.L.; Wang, X.G.; Hu, B.; Zhang, L.; Zhang, W.; Si, H.R.; Zhu, Y.; Li, B.; Huang, C.L.; et al. A pneumonia outbreak associated with a new coronavirus of probable bat origin. Nature 2020, 579, 270-273. [CrossRef] [PubMed]

2. Zhu, N.; Zhang, D.; Wang, W.; Li, X.; Yang, B.; Song, J.; Zhao, X.; Huang, B.; Shi, W.; Lu, R.; et al. A Novel Coronavirus from Patients with Pneumonia in China, 2019. N. Engl. J. Med. 2020, 382, 727-733. [CrossRef] [PubMed]

3. Centers for Disease Control and Prevention. Available online: https://www.cdc.gov/coronavirus/2019-ncov/cases-updates/ variant-surveillance/variant-info.html (accessed on 29 March 2021).

4. Bosch, B.J.; van der Zee, R.; de Haan, C.A.; Rottier, P.J. The coronavirus spike protein is a class I virus fusion protein: Structural and functional characterization of the fusion core complex. J. Virol. 2003, 77, 8801-8811. [CrossRef] [PubMed]

5. Wrapp, D.; Wang, N.; Corbett, K.S.; Goldsmith, J.A.; Hsieh, C.L.; Abiona, O.; Graham, B.S.; McLellan, J.S. Cryo-EM structure of the 2019-nCoV spike in the prefusion conformation. Science 2020, 367, 1260-1263. [CrossRef] [PubMed]

6. Ou, X.; Liu, Y.; Lei, X.; Li, P.; Mi, D.; Ren, L.; Guo, L.; Guo, R.; Chen, T.; Hu, J.; et al. Characterization of spike glycoprotein of SARS-CoV-2 on virus entry and its immune cross-reactivity with SARS-CoV. Nat. Commun. 2020, 11, 1620. [CrossRef] [PubMed]

7. Piccoli, L.; Park, Y.J.; Tortorici, M.A.; Czudnochowski, N.; Walls, A.C.; Beltramello, M.; Silacci-Fregni, C.; Pinto, D.; Rosen, L.E.; Bowen, J.E.; et al. Mapping Neutralizing and Immunodominant Sites on the SARS-CoV-2 Spike Receptor-Binding Domain by Structure-Guided High-Resolution Serology. Cell 2020, 183, 1024-1042.e1021. [CrossRef] [PubMed]

8. Korber, B.; Fischer, W.M.; Gnanakaran, S.; Yoon, H.; Theiler, J.; Abfalterer, W.; Hengartner, N.; Giorgi, E.E.; Bhattacharya, T.; Foley, B.; et al. Tracking Changes in SARS-CoV-2 Spike: Evidence that D614G Increases Infectivity of the COVID-19 Virus. Cell 2020, 182, 812-827.e819. [CrossRef] [PubMed]

9. Zhou, B.; Thao, T.T.N.; Hoffmann, D.; Taddeo, A.; Ebert, N.; Labroussaa, F.; Pohlmann, A.; King, J.; Steiner, S.; Kelly, J.N.; et al. SARS-CoV-2 spike D614G change enhances replication and transmission. Nature 2021, 592, 122-127. [CrossRef] [PubMed]

10. Weissman, D.; Alameh, M.G.; de Silva, T.; Collini, P.; Hornsby, H.; Brown, R.; LaBranche, C.C.; Edwards, R.J.; Sutherland, L.; Santra, S.; et al. D614G Spike Mutation Increases SARS CoV-2 Susceptibility to Neutralization. Cell Host Microbe 2021, 29, 23-31 e24. [CrossRef] [PubMed]

11. Tang, J.W.; Tambyah, P.A.; Hui, D.S. Emergence of a new SARS-CoV-2 variant in the UK. J. Infect. 2021, 82, e27-e28. [CrossRef] [PubMed]

12. Tegally, H.; Wilkinson, E.; Giovanetti, M.; Iranzadeh, A.; Fonseca, V.; Giandhari, J.; Doolabh, D.; Pillay, S.; San, E.J.; Msomi, N.; et al. Emergence and rapid spread of a new severe acute respiratory syndrome-related coronavirus 2 (SARS-CoV-2) lineage with multiple spike mutations in South Africa. medRxiv 2020. [CrossRef]

13. Campbell, F.; Archer, B.; Laurenson-Schafer, H.; Jinnai, Y.; Konings, F.; Batra, N.; Pavlin, B.; Vandemaele, K.; Van Kerkhove, M.D.; Jombart, T.; et al. Increased transmissibility and global spread of SARS-CoV-2 variants of concern as at June 2021. Euro Surveill 2021, 26, 2100509. [CrossRef]

14. Beucher, G.; Blondot, M.-L.; Celle, A.; Pied, N.; Recordon-Pinson, P.; Esteves, P.; Faure, M.; Métifiot, M.; Lacomme, S.; Dacheaux, D.; et al. SARS-CoV-2 transmission via apical syncytia release from primary bronchial epithelia and infectivity restriction in children epithelia. bioRxiv 2021. [CrossRef]

15. Jary, A.; Leducq, V.; Malet, I.; Marot, S.; Klement-Frutos, E.; Teyssou, E.; Soulie, C.; Abdi, B.; Wirden, M.; Pourcher, V.; et al. Evolution of viral quasispecies during SARS-CoV-2 infection. Clin. Microbiol Infect. 2020, 26, 1560.e1-1560.e4. [CrossRef] 